\title{
Production of Chlorine Dioxide Using Hydrogen Peroxide and Chlorates
}

\author{
Mayra K. S. Monteiro ${ }^{1,2}$, Ángela Moratalla ${ }^{2}$ (D) Cristina Sáez ${ }^{2}$ (D) Elisama V. Dos Santos ${ }^{1}$ (D) \\ and Manuel A. Rodrigo $2, *$ (D)
}

1 Environmental and Applied Electrochemical Laboratory, School of Science and Technology, Federal University of Rio Grande do Norte, Lagoa Nova, Natal CEP 59078-970, Brazil; mayra.kerolly@gmail.com (M.K.S.M.); elisamavieira@ect.ufrn.br (E.V.D.S.)

2 Department of Chemical Engineering, Faculty of Chemical Sciences and Technologies, University of Castilla-La Mancha, 13005 Ciudad Real, Spain; angela.moratalla@uclm.es (Á.M.); cristina.saez@uclm.es (C.S.)

* Correspondence: manuel.rodrigo@uclm.es

check for updates

Citation: Monteiro, M.K.S.; Moratalla, Á.; Sáez, C.; Dos Santos, E.V.; Rodrigo, M.A. Production of Chlorine Dioxide Using Hydrogen Peroxide and Chlorates. Catalysts 2021, 11, 1478. https://doi.org/ $10.3390 /$ catal11121478

Academic Editors: Manuel Sánchez-Polo, Federica Menegazzo and Helder T. Gomes

Received: 19 October 2021

Accepted: 1 December 2021

Published: 2 December 2021

Publisher's Note: MDPI stays neutral with regard to jurisdictional claims in published maps and institutional affiliations.

Copyright: (c) 2021 by the authors. Licensee MDPI, Basel, Switzerland. This article is an open access article distributed under the terms and conditions of the Creative Commons Attribution (CC BY) license (https:/ / creativecommons.org/licenses/by/ $4.0 /)$.

\begin{abstract}
Chlorine dioxide was produced by the reduction of chlorate with hydrogen peroxide in strongly acidic media. To avoid reaction interference during measuring procedures, UV spectra were acquired to monitor the chlorate reduction. This reduction led to the formation of chlorine dioxide and notable concentrations of chlorite and hypochlorous acid/chlorine, suggesting that the hydrogen peroxide:chlorate ratio is important. Once chlorates are transformed to chlorine dioxide, the surplus hydrogen peroxide promoted the further reaction of the chlorinated species down to less-important species. Moreover, chlorine dioxide was stripped with the outlet gas flow. A linear relationship was established between the amount of limiting reagent consumed and the maximum height of the absorption peak at $360 \mathrm{~nm}$ after testing with different ratios of hydrogen peroxide and chlorate, allowing calculations of the maximum amount of chlorine dioxide formed. To verify the reproducibility of the method, a test with four replicates was conducted in a hydrogen peroxide/chlorate solution where chlorine dioxide reduction was not promoted due to the presence of surplus chlorate in the reaction medium after the test. Results confirmed the efficient formation of this oxidant, with maximum concentrations of $8.0 \pm 0.33 \mathrm{mmol} \mathrm{L}^{-1}$ in $400-450 \mathrm{~min}$ and a conversion percentage of $97.6 \%$. Standard deviations of $0.14-0.49 \mathrm{mmol} \mathrm{L}^{-1}$ were obtained during oxidation (3.6-6.5\% of the average), indicating good reproducibility.
\end{abstract}

Keywords: hydrogen peroxide; chlorates; chlorine dioxide; UV-vis spectrophotometry

\section{Introduction}

Chlorine dioxide $\left(\mathrm{ClO}_{2}\right)$ is an oxidizing gas that is extensively used as a bleaching and disinfectant reagent [1]. The paper industry regularly consumes large amounts of $\mathrm{ClO}_{2}$ where, because of environmental concerns, $\mathrm{ClO}_{2}$ substitutes molecular chlorine in pulp bleaching. $\mathrm{ClO}_{2}$ was also considered suitable for application in the disinfection of drinking water, and, opposite to other chlorinated disinfectants, it prevents the formation of chlorinated organic compounds [2-4]. It has several other advantages over chlorine. For example, unlike with chlorine, the disinfection capability of $\mathrm{ClO}_{2}$ does not deteriorate with increasing $\mathrm{pH}[5,6]$. In addition, $\mathrm{ClO}_{2}$ is also stable in hydraulic systems for longer periods and provides microbiological protection to water for durations ranging from hours to a few days. Research is ongoing on many different applications relating to disinfection as has been recently pointed out with the COVID-19 pandemic [7-9].

The chemistry of $\mathrm{ClO}_{2}$ is complex as compared to those of other chlorine compounds because of its high reactivity. Two important properties are its high solubility in water and partial pressure above $76 \mathrm{~mm}$ of $\mathrm{Hg}$ [10]. $\mathrm{ClO}_{2}$ is a stable compound known to possess biocidal characteristics, even at low concentrations $\left(0.001 \mathrm{mmol} \mathrm{L}^{-1}\right)$. It acts as an oxidizing 
biocide and controls the growth of Gram-positive and Gram-negative bacteria by inhibiting the transport of nutrients through the cell wall and also by destroying it [11]. Its biocidal effectiveness is associated with its good target selectivity as compared to those of other known oxidants, such as ozone or chlorine, which are more reactive and mostly consumed by organic matter. Hence, low concentrations of $\mathrm{ClO}_{2}$ can be used to obtain a longer stable residual effect [12]. Although there are other routes, $\mathrm{ClO}_{2}$ can be produced by reacting sodium chlorate in a concentrated acid solution with reducing agents such as sulfur dioxide, methanol, oxalic acid, hydrogen peroxide, hydrochloric acid, or sodium chloride. However, hydrogen peroxide is replacing the other reagents in the reduction of chlorate, because this reaction involves an eco-friendly environmental step where the main by-product formed is oxygen, according to Equation (1) [13].

$$
\mathrm{ClO}_{3}{ }^{-}+1 / 2 \mathrm{H}_{2} \mathrm{O}_{2}+\mathrm{H}^{+} \rightarrow \mathrm{ClO}_{2(\mathrm{aq})}+\frac{1}{2} \mathrm{O}_{2}+\mathrm{H}_{2} \mathrm{O}
$$

This reduction does not only lead to the formation of $\mathrm{ClO}_{2}$, but also to the generation of chlorine and hypochlorous acid/chlorine in high concentrations, which highlights the importance of keeping the ratio between hydrogen peroxide and chlorate in suitable values $[7,14,15]$. More recently, the production of $\mathrm{ClO}_{2}$ using electrochemical technology was studied using mixed metal oxide (MMO) electrodes in the presence of chlorite [16-19] and Boron Doped Diamond BDD anodes were used to promote the evolution of chlorine species $[20,21]$.

$\mathrm{ClO}_{2}$ was determined for the first time in the mid-1990s by an indirect analysis through the mass balance of all chlorinated species [22,23]. Additionally, chromatographic, titration and iodometric techniques were employed. These methods present important drawbacks such as the need for sample pretreatment, high consumption of chemicals and large amounts of waste. In fact, the reactivity of chlorine species is a very important input during conventional methods of measurement. Thus, based on the high reactivity of chlorine species with other chemicals, even during the application of chromatographic techniques, it can be understood that the measurement methods may interfere with the determination of real concentrations in which these species are contained in reaction media [22]. Such analysis parameters are limited because they are dependent on the appropriate $\mathrm{pH}$, temperature, and addition of specific reagents [24] and even, the reagents used in the measurement can influence the speciation.

With the aim of addressing these concerns and considering previous related research, in this study, the production of $\mathrm{ClO}_{2}$ by the reduction of chlorates with hydrogen peroxide in strongly acidic reaction media is confirmed. Additionally, it is proposed its verification by following the course of the reaction spectrophotometrically, as this approach does not interfere with the progress of reduction and allows the quantitative determination of $\mathrm{ClO}_{2}, \mathrm{HClO}, \mathrm{Cl}_{2}, \mathrm{Cl}^{-}$during the reaction. The reproducibility in the production of these important oxidants was also confirmed. The findings also provide insights into the mechanisms of this production.

\section{Results and Discussion}

\subsection{Production of Chlorine Dioxide}

It is important to monitor reactions based on methodologies that entail a low degree of interaction with the chlorinated species. UV-vis spectrophotometry is a suitable choice because the absorption peaks of the different species of interest required to evaluate the reactivity are sufficiently separated in the UV-vis spectra. This is clearly seen in Figure 1a, which shows the spectra of different species of interest for evaluating the chemistry of $\mathrm{ClO}_{2}$. The spectra show that the maximum absorption peaks for chlorate, chlorite, chlorine, hypochlorous acid, and $\mathrm{ClO}_{2}$ occur at $200 \mathrm{~nm}, 230 \mathrm{~nm}, 310 \mathrm{~nm}, 323 \mathrm{~nm}$, and $360 \mathrm{~nm}$, respectively, all of which are sufficiently separated from the others, allowing their monitoring in order to understand their interaction in the reaction system. To deconvolute the contribution of each species from the spectra, the features of the spectra of each compound 
were modeled by means of Gaussians, and their contribution was added to have a complete model of the spectra, where the weight of each of these gaussian curves is expected to be proportional to the concentration of the species according to the Lambert-Beer law. Then the experimental weights were obtained by fitting the experimental data coming from the spectra using a least-square optimization methodology.

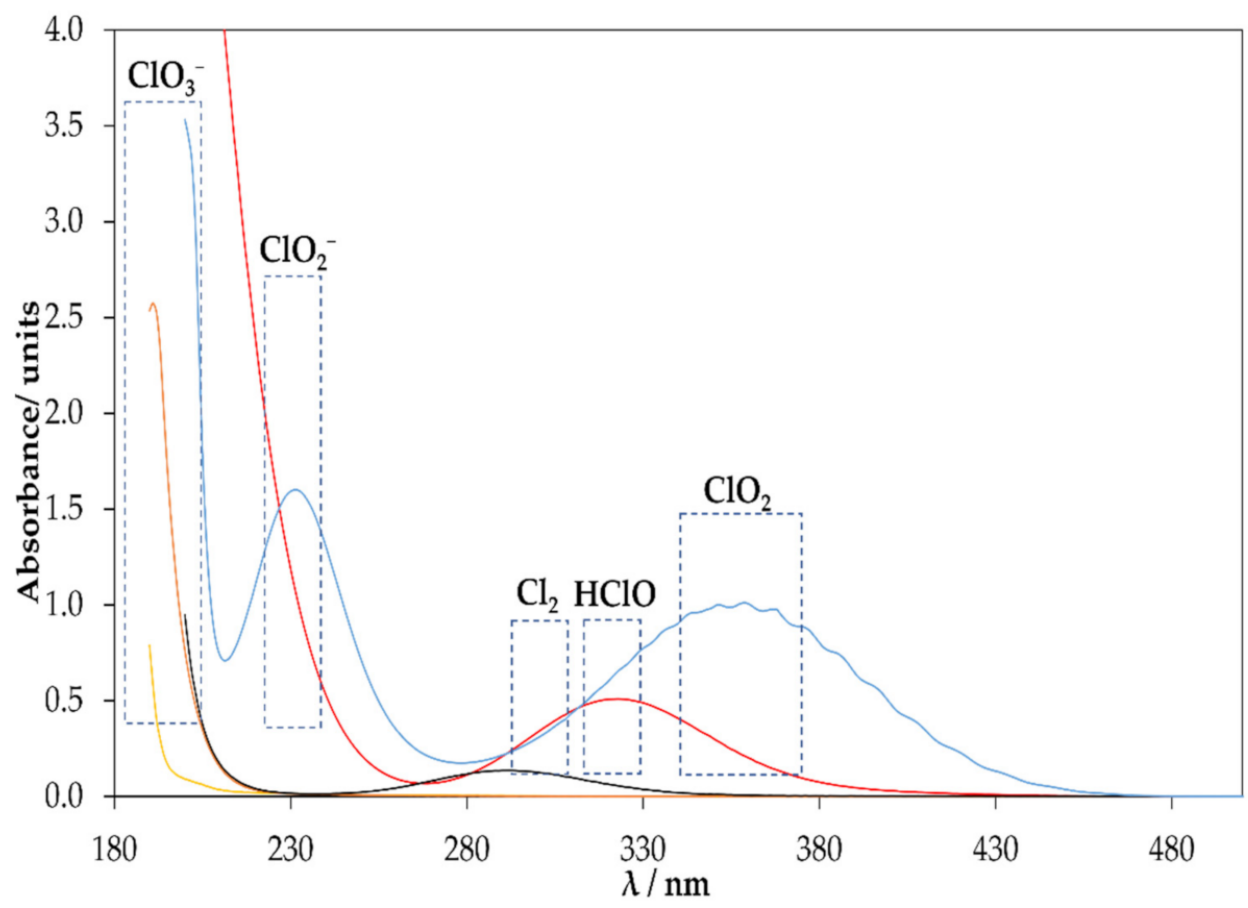

(a)

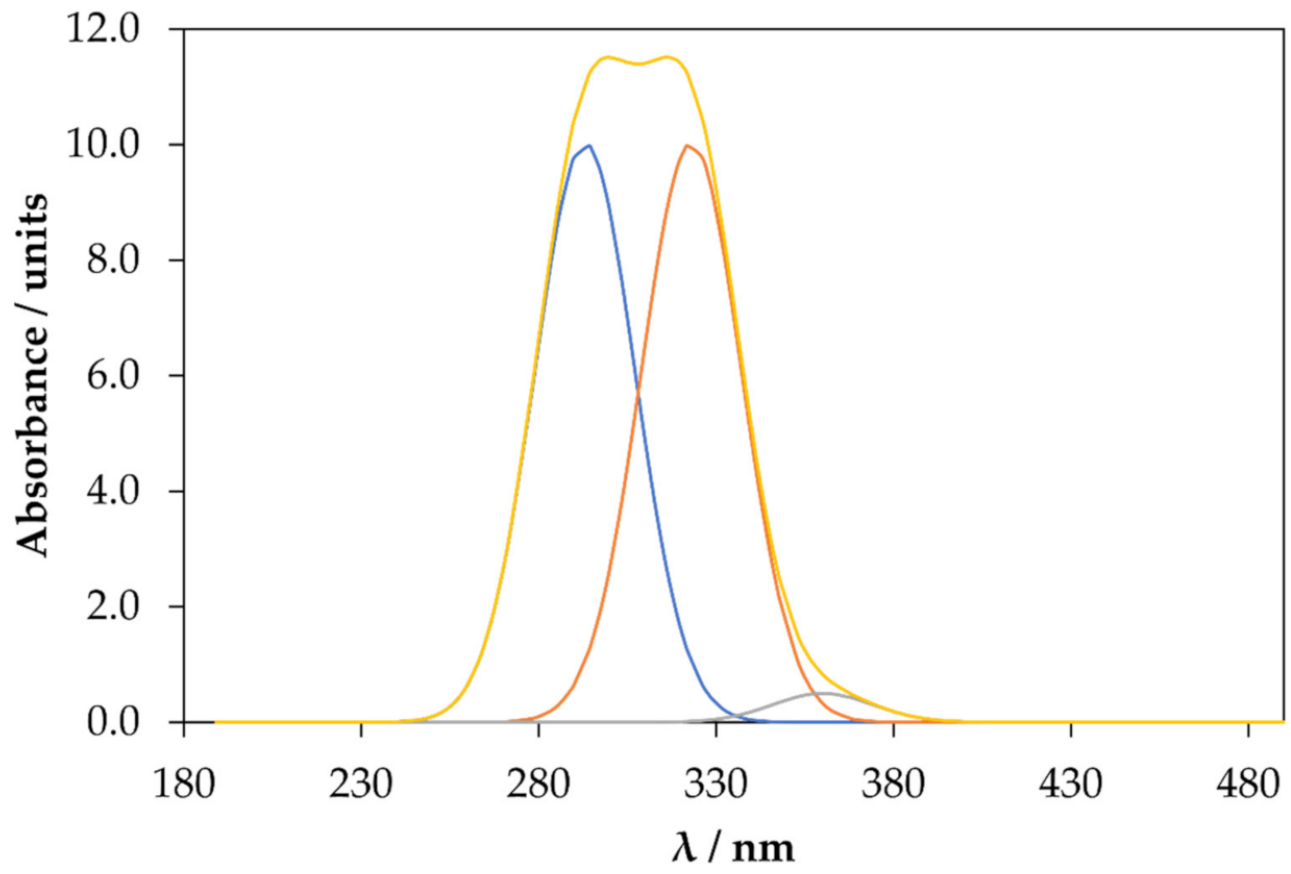

(b)

Figure 1. UV-vis spectra (a) and deconvoluted UV-vis spectra lines (b) of samples containing $\mathrm{H}_{2} \mathrm{SO}_{4}$ $5 \mathrm{M}\left(\right.$ (一), $\mathrm{ClO}_{3}{ }^{-} 4.7 \mathrm{mM}\left(\right.$ ( ), $\mathrm{HClO} 6.7 \mathrm{mM}\left(\right.$ ( ), $\mathrm{ClO}^{-} 5.4 \mathrm{mM}($ ( ) , chlorite $1.5 \mathrm{mM}($ ( ) . 
Considering that, Figure 2 shows changes in the UV spectra of a mixture containing $5 \mathrm{~mL}$ of an aqueous solution containing $5 \mathrm{~g} / \mathrm{L} \mathrm{NaClO}_{3}, 25 \mathrm{~mL}$ of $5 \mathrm{M} \mathrm{H}_{2} \mathrm{SO}_{4}$ and $5 \mathrm{~mL}$ of an aqueous solution containing $3.3 \mathrm{~g} / \mathrm{L} \mathrm{H}_{2} \mathrm{O}_{2}$ kept at $60{ }^{\circ} \mathrm{C}$ for $24 \mathrm{~h}$. Considering the high reactivity of the species, and as explained before, this method is expected to allow us to monitor the changes in the key species involved without interfering in the system. The peak at $360 \mathrm{~nm}$ is associated with the formation of $\mathrm{ClO}_{2}$. As seen, the combination in strongly acidic media of chlorates and hydrogen peroxide produces high concentrations of this oxidant. In addition, over the $24 \mathrm{~h}$ of testing, there are significant changes in the reaction media. The formation of $\mathrm{ClO}_{2}$, chlorite (maximum absorption peak near $230 \mathrm{~nm}$ ), hypochlorous acid (maximum absorption peak at $323 \mathrm{~nm}$ ) and chlorine (maximum absorption peak at $310 \mathrm{~nm}$ ) was observed. Regarding chlorite formation, the high concentrations of chlorate at the beginning of the test masked the peak, which, when combined with that of chlorine, resulted in a broader peak. When chlorate is depleted, the peak is more clearly observed. Hence, when mixing chlorates and hydrogen peroxide in strongly acidic media many reactions are observed to occur simultaneously. This set of reactions results in the formation of $\mathrm{ClO}_{2}$, chlorine/hypochlorous acid, and chlorite in the reaction mixture and there is an interconversion of these species during the complete duration of the test.

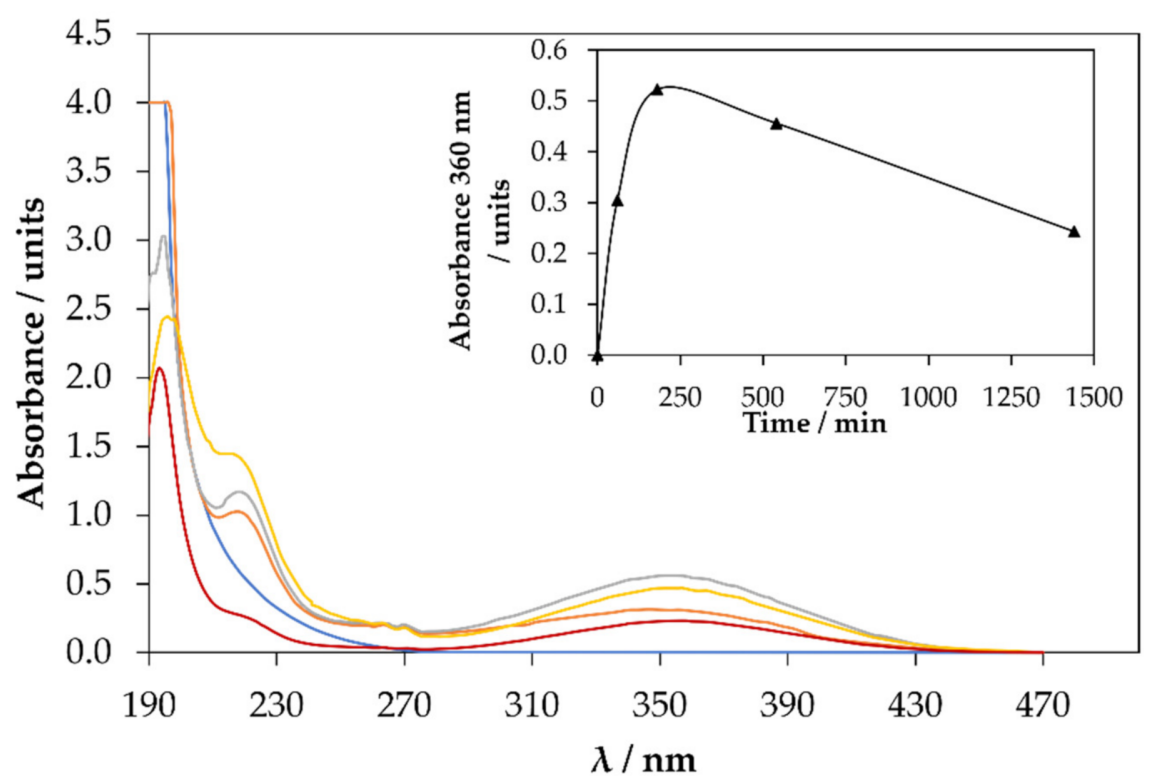

Figure 2. Changes in the UV-vis spectrum over $24 \mathrm{~h}$ during the liquid reaction of chlorate and hydrogen peroxide in strongly acidic media. (-) $0 \mathrm{~h},(-) 1 \mathrm{~h},(-) 3 \mathrm{~h},(-) 9 \mathrm{~h}$ and (-) $24 \mathrm{~h}$. The inset panel shows the absorbance of chlorine dioxide $(360 \mathrm{~nm})$ produced in the system during the reaction.

It is worth observing the time course of the peak at $360 \mathrm{~nm}$ over the reaction time (for $\mathrm{ClO}_{2}$ ) which increases up to a maximum absorption of 0.522 units at the third hour of reaction and then, it decreases gradually. At the end of the treatment, the amounts of chlorate and hydrogen peroxide consumed were 5.55 and $11.94 \mathrm{mmol} / \mathrm{L}$, with decreases in the concentration from 5.26 to $0.91 \mathrm{mmol} \mathrm{L}^{-1}$ in the case of chlorate and from 21.78 down to $1.91 \mathrm{mmol} \mathrm{L}^{-1}$ in the case of hydrogen peroxide. The $\mathrm{H}_{2} \mathrm{O}_{2} / \mathrm{ClO}_{3}{ }^{-}$ratio between the consumed reagents is 2.15 , slightly higher than the ratio of 2 which is stoichiometric for the $\mathrm{ClO}_{2}$ production (Equation (1)), and which may suggest that once chlorine dioxide is formed, the reduction of the chlorinated species continues, leading to the formation of other species, as also is confirmed by the occurrence of a chlorite peak (Equation (2)).

$$
2 \mathrm{ClO}_{2}+\mathrm{H}_{2} \mathrm{O}_{2} \rightarrow 2 \mathrm{H}^{+}+2 \mathrm{ClO}_{2}^{-}+\mathrm{O}_{2}
$$


Regarding the production of gaseous $\mathrm{ClO}_{2}$, samples of gas $(5 \mathrm{~mL})$ were bubbled into a solution containing iodide, producing iodine. The oxidation capacity of the gaseous flow is shown in Figure 3, confirming the viability of the production of the gaseous oxidant reagent. The transient delay in the observation of the maximum production can be explained in terms of gas transport.

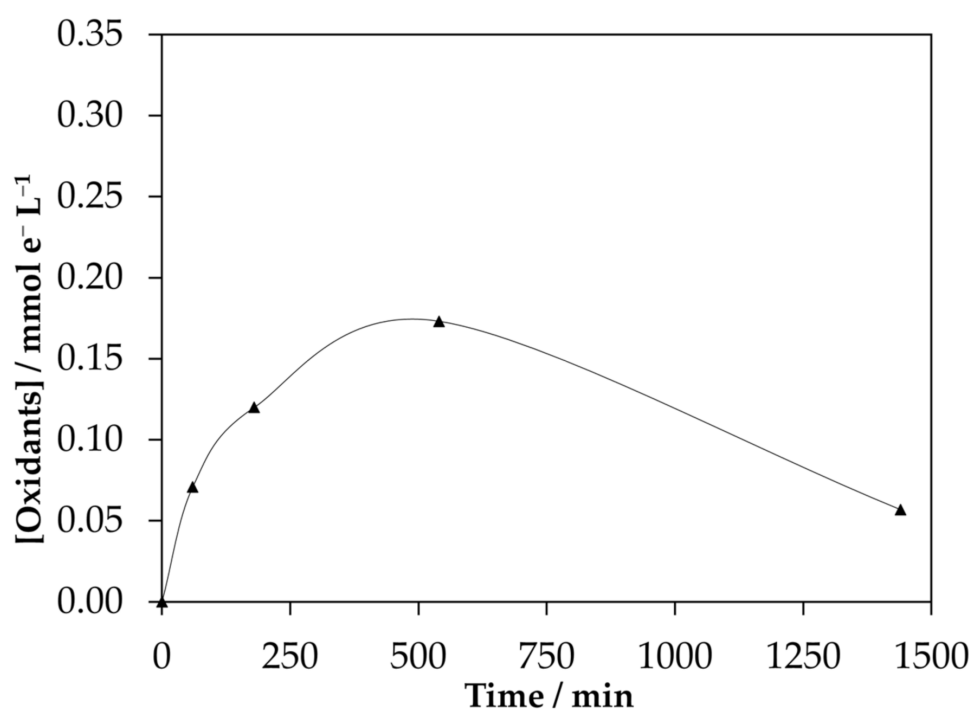

Figure 3. Concentration of total oxidants in the gas phase.

Several additional tests were carried out changing the ratios between hydrogen peroxide and chlorate after considering the results obtained in this previous test. The concentrations of chlorate and hydrogen peroxide were monitored in all tests, and the limiting reagent concentration was plotted vs. the maximum height of the $360 \mathrm{~nm}$ absorption peak. The results are shown in Figure 4. As seen, regardless of the variability, which is associated with the presence of many other species which may have an impact on the photometric response, there is a clear relationship that allows for calculating the maximum amount of $\mathrm{ClO}_{2}$ produced. In all these tests, the absorbance at $360 \mathrm{~nm}$ increases up to a maximum, then subsequently decreases. This supports those consecutive reactions that occur in the system if hydrogen peroxide remains in the reaction medium.

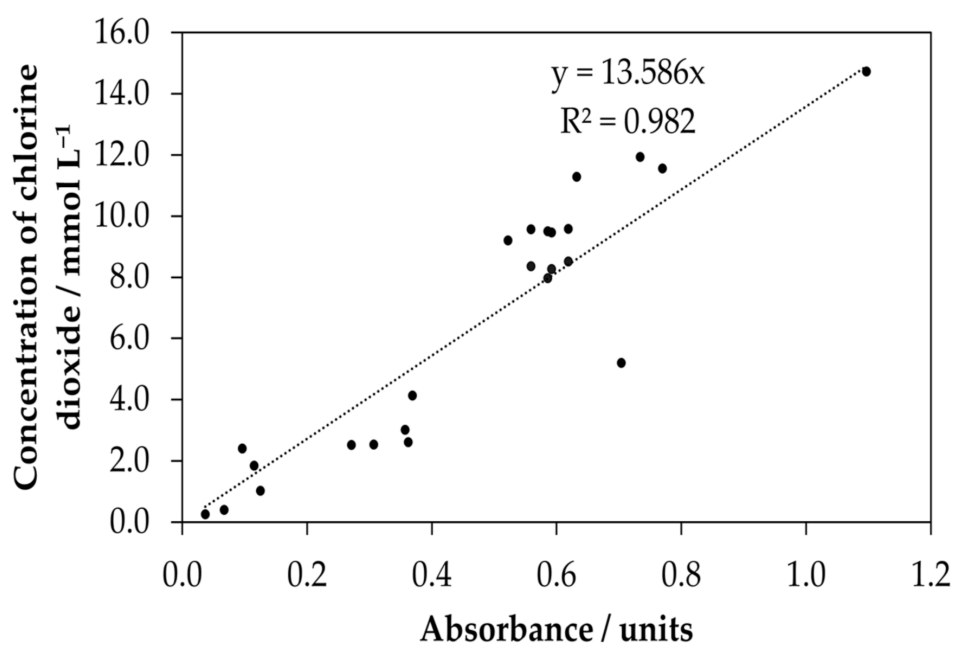

Figure 4. Relationship between the maximum reached in the absorbance at $360 \mathrm{~nm}$ and the amount of limiting reagent reacted in the interaction between hydrogen peroxide and chlorates. 


\subsection{Reproducibility in the Production of $\mathrm{ClO}_{2}$}

Figure 5 shows the time course of the concentration of $\mathrm{ClO}_{2}$ produced in the liquid reaction media when $10 \mathrm{~mL}$ of $\mathrm{HClO}_{3}\left(5 \mathrm{~g} / \mathrm{L} \mathrm{NaClO}_{3}\right)$ are mixed with $4 \mathrm{~mL}$ of $\mathrm{H}_{2} \mathrm{O}_{2}$ ( $3.3 \mathrm{~g} / \mathrm{L}$ ) and $25 \mathrm{~mL}$ of $\mathrm{H}_{2} \mathrm{SO}_{4} 5 \mathrm{M}$, at a constant temperature of $68^{\circ} \mathrm{C}$. The reaction tests lasted after $24 \mathrm{~h}$ and were repeated four times to check reproducibility. Dosing between chlorates and hydrogen peroxide was $1.2 \mathrm{mmol}$ chlorate/mmol hydrogen peroxide. The concentrations of hydrogen peroxide and chlorate decrease almost immediately from the initial 9.95 and $12.03 \mathrm{mmol} \mathrm{L}^{-1}$ down to $5.74 \pm 0.01$ and $9.62 \pm 0.24 \mathrm{mmol} \mathrm{L}^{-1}$ and, after $24 \mathrm{~h}$, to $0.73 \pm 0.08$ and $3.83 \pm 0.23 \mathrm{mmol} \mathrm{L}^{-1}$, respectively. This confirms a fast interaction between both reagents, providing insight into further reactions during the aging of the reaction mixture. This also supports that reaction proceeds stoichiometry because hydrogen peroxide is almost exhausted during the process.

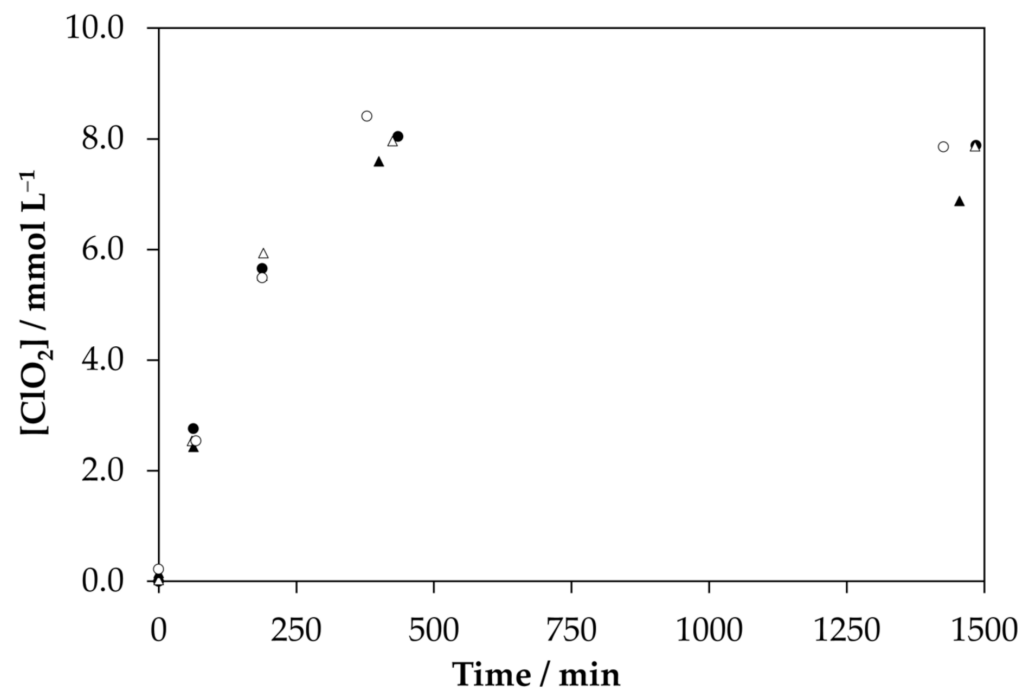

Figure 5. Concentration of $\mathrm{ClO}_{2}$ produced in the liquid phase. $\mathrm{T}^{\mathrm{a}}$ Reactor $=68^{\circ} \mathrm{C}$. Test $1(\bullet)$, test $2(\Delta)$, test $3(\mathbf{\Lambda})$ and test $4(\bigcirc) . n=4$.

As seen, the reproducibility of the four tests is very good, with standard deviations in the range $0.14-0.49 \mathrm{mmol} \mathrm{L}^{-1}$ during the oxidation (3.6-6.5\% of the average values). Maximum concentrations of $8.0 \pm 0.33 \mathrm{mmol} \mathrm{L}^{-1}$ were obtained in $400-450 \mathrm{~min}$ of reaction. The conversion of chlorates into $\mathrm{ClO}_{2}$ reaches $97.6 \%$, for these conditions, indicating that chlorate anions are the limiting reagents (despite there still being important concentrations of surplus chlorate after the $24 \mathrm{~h}$ tests). Decreases at longer times may be explained in terms of the stripping of chlorine dioxide to the gas phase.

Thus, and as observed in Figure 6, gas-phase oxidants are collected from the reaction system. This gas has a very important oxidation capacity, as it is confirmed with the formation of iodine, following the bubbling of the gas through a solution of $1.0 \mathrm{~g} \mathrm{~L}^{-1} \mathrm{KI}$. In this case, the standard deviations range between 0.006 and $0.051 \mathrm{mmol} \mathrm{e}^{-} \mathrm{L}^{-1}(9.8-28.75 \%$ with respect to the corresponding average value) and the maximum amount formed was $0.22 \pm 0.02 \mathrm{mmol} \mathrm{e}^{-} \mathrm{L}^{-1}$. 


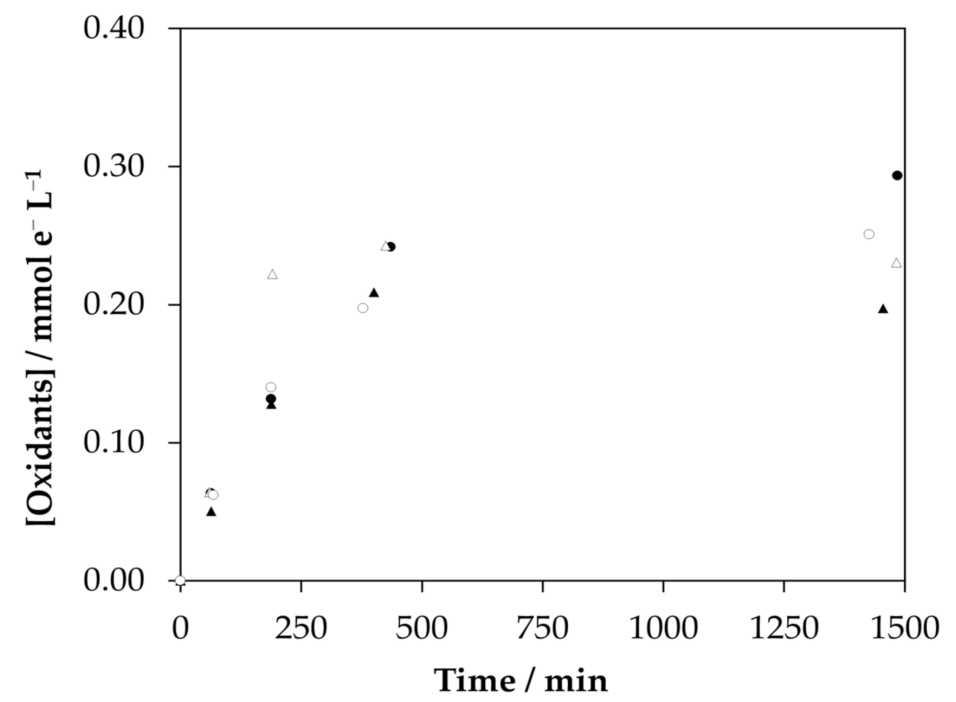

Figure 6. Concentration of total oxidants in the gas phase. Test $1(\bullet)$, test $2(\Delta)$, test $3(\Delta)$ and test $4(\bigcirc)$.

In Figure 7, the UV-vis spectra are shown in the four tests. As it can be observed, these spectra do not only confirm the reproducibility of the tests made but also points out that no important concentrations of hypochlorous acid (absorption peak at $323 \mathrm{~nm}$ ) nor chlorine (absorption peak at $310 \mathrm{~nm}$ ) are produced in the reaction system.

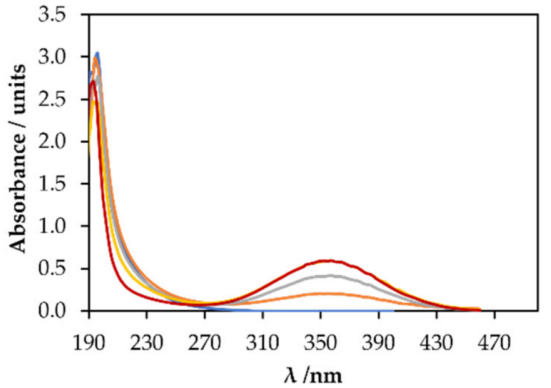

(a)

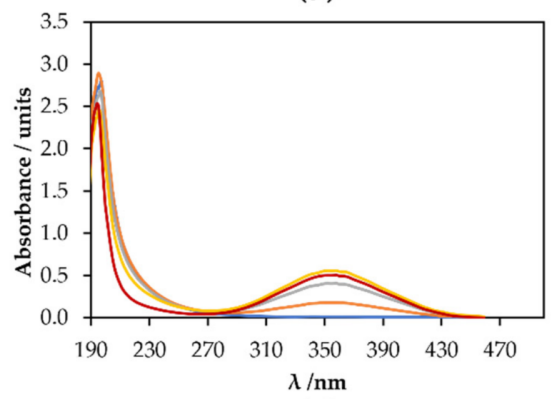

(c)

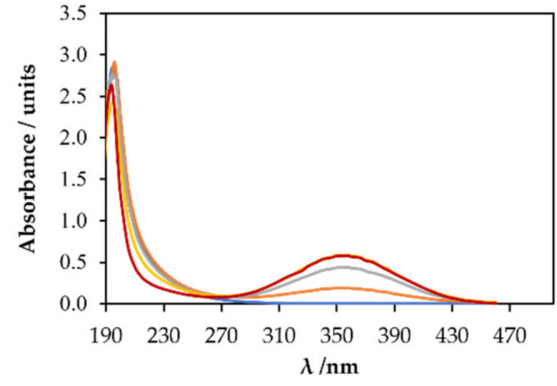

(b)

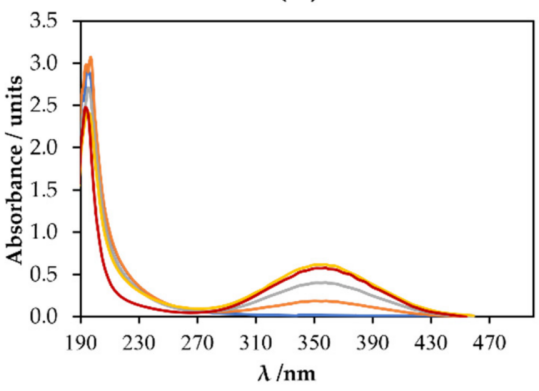

(d)

Figure 7. UV-vis spectra of samples (liquid phase) taken at different reaction times during the four tests carried out (a) test 1 ; (b) test 2 ; (c) test 3 ; (d) test 4 . (-) $0 \mathrm{~h},($ - $) 1 \mathrm{~h},(\boldsymbol{C}) 3 \mathrm{~h},(\mathbf{C}) 9 \mathrm{~h}$ and (-) $24 \mathrm{~h}$.

This result is important because the reactivity of chlorates and hydrogen peroxide is rather complex. In fact, paying attention to the UV-vis spectra, absorption in the nearness of $230 \mathrm{~nm}$ (chlorite) can be seen over the reaction time, decreasing down to almost negligible at $24 \mathrm{~h}$ of reactions. This may indicate that chlorite is formed during the process from the very first moments of the reaction. 


\section{Materials and Methods}

\subsection{Chemicals}

Sodium chlorate (ACS reagent, $\geq 99.0 \%)$, hydrogen peroxide $(33 \% w / v)$ were supplied by Merck (Darmstadt, Germany) and Labbox (Vilassar de Dalt, Barcelona, Spain), respectively. Sulfuric acid (90-91\%) and potassium iodide (ACS reagent, $\geq 99.0 \%$ ) were purchased from Scharlab (Sentmenat, Barcelona, Spain). Acetone and sodium carbonate (analytical grade, from Merk) were used for the mobile phase to determine chlorates. Titanium (IV) oxysulfate (1.9-2.1\%, from Merck) was used as indicator of hydrogen peroxide. All solutions were prepared with double deionized water obtained from a Milipore Mili-Q system $\left(18.2 \mathrm{M} \Omega \mathrm{cm}, 25^{\circ} \mathrm{C}\right)$.

\subsection{Experimental Setup}

Experiments were carried out in completely closed glass reactors $(250 \mathrm{~mL})$. Different volumes of chlorate $\left(5 \mathrm{~g} \mathrm{~L}^{-1}\right)$ and hydrogen peroxide $\left(3.3 \mathrm{~g} \mathrm{~L}^{-1}\right)$ were added to the reactor for $\mathrm{ClO}_{2}$ formation. To achieve a strongly acidic $\mathrm{pH}, 25 \mathrm{~mL}$ of sulphuric acid $(5 \mathrm{M})$ was added in all cases. The mixture was stirred softly (350 rpm) at constant temperature (60 or $68{ }^{\circ} \mathrm{C}$ ) by using a thermostatic bath for $24 \mathrm{~h}$. These studies were limited to temperature range because of concerns about the possibility of chlorine dioxide decomposition at higher temperatures $[8,22]$. Samples of the liquid and gas phases were collected periodically to quantify the evolution of $\mathrm{ClO}_{2}$.

\subsection{Characterization Methods}

Chlorates $\left(\mathrm{ClO}_{3}{ }^{-}\right)$were determined by ion chromatography using a Metrohm 930 Compact IC Flex (Madrid, Spain) coupled to a conductivity detector. Mobile phase is composed of 85:15 v/v $3.6 \mathrm{mM} \mathrm{Na}_{2} \mathrm{CO}_{3} /$ Acetone solution and flowed at $0.8 \mathrm{~mL} \mathrm{~min}{ }^{-1}$ through a Metrosep A Supp 7 column. The temperature of the oven was $40{ }^{\circ} \mathrm{C}$ and the injection volume was $20.0 \mu \mathrm{L}$. Hydrogen peroxide was analyzed by spectrophotometry due to the complex formed between $\mathrm{H}_{2} \mathrm{O}_{2}$ and $\mathrm{Ti}^{2+}$ [25] at a wavelength of $410 \mathrm{~nm}$. The chorine species in liquid phase were monitored by spectrophotometry using a UV-1700 Shimadzu Spectrophotometer (Duisbur, Germany). The characteristic wavelengths at which absorb chloride $\left(\mathrm{Cl}^{-}\right)$, hypochlorous acid $(\mathrm{HClO})$, chlorine $\left(\mathrm{Cl}_{2}\right)$ and chlorine dioxide $\left(\mathrm{ClO}_{2}\right)$ were 230, 323, 310 and $360 \mathrm{~nm}$, respectively. $\mathrm{ClO}_{2}$ determination was also carried out spectrophotometrically using a calibration curve of standard $\mathrm{ClO}_{2}$, which ranged from $0-14.73 \mathrm{mmol} \mathrm{L}^{-1}$.

Regarding the gaseous phase, samples of $5 \mathrm{~mL}$ of gas were taken and bubbled into water for measuring the spectra or into a solution containing iodide, producing its transformation into iodine. In this latter case, the iodine solution was titrated with sodium thiosulphate to quantify oxidants.

\section{Conclusions}

From this work, the following conclusions can be drawn:

- $\mathrm{ClO}_{2}$ can be produced by the reduction of chlorate with hydrogen peroxide in strongly acidic media. Further reduced chlorinates species can be produced when chlorate is exhausted from the reaction media. This is because $\mathrm{ClO}_{2}$ is further reduced to chlorite and even to hypochlorous acid/chlorine.

- There is a good relationship between the height of the absorption peak at $360 \mathrm{~nm}$ and the amount of the limiting reagent consumed in the production of chlorine dioxide, which allows the use of the spectrophotometric measurement to quantify this important oxidant. A value of $13.586 \mathrm{mmol} /$ absorption unit was found by fitting experimental results obtained in a set of tests in which the ratio of hydrogen peroxide/chlorate was evaluated.

- Part of the chlorine dioxide produced is stripped to the gas flow producing gas with high oxidation capacity. 
- Reproducibility of the reaction is very high with standard deviations in the range $0.14-0.49 \mathrm{mmol} \mathrm{L}^{-1}$ during the oxidation (3.6-6.5\% of the average values). If a suitable hydrogen peroxide/chlorate is used and chlorate is not exhausted from the reaction media, production of chlorine dioxide can be very high with conversions near $100 \%$.

Author Contributions: Conceptualization: Á.M., C.S., E.V.D.S. and M.A.R., methodology: Á.M., validation: C.S., E.V.D.S. and M.A.R., formal analysis: Á.M. and M.K.S.M., investigation: Á.M. and M.K.S.M., resources: C.S. and M.A.R., data curation: Á.M. and M.K.S.M., writing-original draft: Á.M., writing-review and editing: C.S., E.V.D.S. and M.A.R., supervision: C.S. and M.A.R., project administration: M.A.R., funding acquisition: M.A.R. All authors have read and agreed to the published version of the manuscript.

Funding: Financial support from the Spanish Agencia Estatal de Investigación through project PID2019-107271RB-I00 (AEI/FEDER, UE) is gratefully acknowledged. M.K.S.M also acknowledges CNPq- Conselho Nacional de Desenvolvimento Científico e Tecnológico for process number 202069/2019-2 (doutorado sanduíche no Exterior-SWE).

Data Availability Statement: Not Applicable.

Conflicts of Interest: The authors declare no conflict of interest.

\section{References}

1. Crump, B.; Ernst, W.R.; Neumann, H.M. Influence of $\mathrm{H}_{2} \mathrm{O}_{2}$ on a chloride-dependent reaction path to chlorine dioxide. AIChE J. 1998, 44, 2494-2500. [CrossRef]

2. Zada, A.; Khan, M.; Khan, M.A.; Khan, Q.; Habibi-Yangjeh, A.; Dang, A.; Maqbool, M. Review on the hazardous applications and photodegradation mechanisms of chlorophenols over different photocatalysts. Environ. Res. 2021, 195, 110742. [CrossRef]

3. Al-Otoum, F.; Al-Ghouti, M.A.; Ahmed, T.A.; Abu-Dieyeh, M.; Ali, M. Disinfection by-products of chlorine dioxide (chlorite, chlorate, and trihalomethanes): Occurrence in drinking water in Qatar. Chemosphere 2016, 164, 649-656. [CrossRef]

4. Herraiz-Carboné, M.; Lacasa, E.; Cotillas, S.; Vasileva, M.; Cañizares, P.; Rodrigo, M.A.; Sáez, C. The role of chloramines on the electrodisinfection of Klebsiella pneumoniae in hospital urines. Chem. Eng. J. 2021, 409, 128253. [CrossRef]

5. Marín, A.; Tudela, J.A.; Garrido, Y.; Albolafio, S.; Hernández, N.; Andújar, S.; Allende, A.; Gil, M.I. Chlorinated wash water and $\mathrm{pH}$ regulators affect chlorine gas emission and disinfection by-products. Innov. Food Sci. Emerg. Technol. 2020, 66, 102533. [CrossRef]

6. Bergmann, H.; Koparal, S. The formation of chlorine dioxide in the electrochemical treatment of drinking water for disinfection. Electrochim. Acta 2005, 50, 5218-5228. [CrossRef]

7. Sales Monteiro, M.K.; Sales Monteiro, M.M.; de Melo Henrique, A.M.; Llanos, J.; Saez, C.; Dos Santos, E.V.; Rodrigo, M.A. A review on the electrochemical production of chlorine dioxide from chlorates and hydrogen peroxide. Curr. Opin. Electrochem. 2021, 27, 100685. [CrossRef]

8. Deshwal, B.R.; Lee, H.K. Kinetics and mechanism of chloride based chlorine dioxide generation process from acidic sodium chlorate. J. Hazard. Mater. 2004, 108, 173-182. [CrossRef] [PubMed]

9. Bergmann, H. Electrochemical disinfection-State of the art and tendencies. Curr. Opin. Electrochem. 2021, 28, 100694. [CrossRef]

10. Deshwal, B.R.; Lee, H.K. Manufacture of chlorine dioxide from sodium chlorate: State of the art. J. Ind. Eng. Chem. 2005, 11, 330-346.

11. Vincenti, S.; de Waure, C.; Raponi, M.; Teleman, A.A.; Boninti, F.; Bruno, S.; Boccia, S.; Damiani, G.; Laurenti, P. Environmental surveillance of Legionella spp. colonization in the water system of a large academic hospital: Analysis of the four-year results on the effectiveness of the chlorine dioxide disinfection method. Sci. Total. Environ. 2019, 657, 248-253. [CrossRef]

12. Lv, J.; Ou, C.; Fu, M.; Xu, Z. Characteristics and transformation pathways of venlafaxine degradation during disinfection processes using free chlorine and chlorine dioxide. Chemosphere 2021, 276, 130147. [CrossRef]

13. Wu, C.T.; Chang, C.Y.; Li, Y.Y.; Kuan, Y.L.; Lin, P.H. An efficiency analysis for the production of chlorine dioxide by the electrolysis of brine in seawater desalination plants. Water Qual. Res. J. 2019, 54, 127-133. [CrossRef]

14. Qian, Y.; Chen, Y.; Jiang, Y.; Zhang, L. A clean production process of sodium chlorite from sodium chlorate. J. Clean. Prod. 2007, 15, 920-926. [CrossRef]

15. Pillai, K.C.; Kwon, T.O.; Park, B.B.; Moon, I.S. Using RuO2 anode for chlorine dioxide production in an un-divided electrochemical cell. Water Sci. Technol. 2010, 61, 2151-2160. [CrossRef]

16. Pillai, K.C.; Kwon, T.O.; Park, B.B.; Moon, I.S. Studies on process parameters for chlorine dioxide production using IrO2 anode in an un-divided electrochemical cell. J. Hazard. Mater. 2009, 164, 812-819. [CrossRef] [PubMed]

17. Brito, C.d.N.; de Araújo, D.M.; Martínez-Huitle, C.A.; Rodrigo, M.A. Understanding active chlorine species production using boron doped diamond films with lower and higher sp3/sp2 ratio. Electrochem. Commun. 2015, 55, 34-38. [CrossRef]

18. Bergmann, M.E.H.; Rollin, J. Product and by-product formation in laboratory studies on disinfection electrolysis of water using boron-doped diamond anodes. Catal. Today 2007, 124, 198-203. [CrossRef] 
19. Ryu, S.Y.; Hoffmann, M.R. Mixed-metal semiconductor anodes for electrochemical water splitting and reactive chlorine species generation: Implications for electrochemicalwastewater treatment. Catalysts 2016, 6, 59. [CrossRef]

20. Mostafa, E.; Reinsberg, P.; Garcia-Segura, S.; Baltruschat, H. Chlorine species evolution during electrochlorination on boron-doped diamond anodes: In-situ electrogeneration of $\mathrm{Cl} 2, \mathrm{Cl} 2 \mathrm{O}$ and $\mathrm{ClO} 2$. Electrochim. Acta 2018, 281, 831-840. [CrossRef]

21. Souza, F.L.; Saéz, C.; Lanza, M.R.V.; Cañizares, P.; Rodrigo, M.A. The effect of the sp3/sp2 carbon ratio on the electrochemical oxidation of 2,4-D with p-Si BDD anodes. Electrochim. Acta 2016, 187, 119-124. [CrossRef]

22. Burke, M.; Hoq, M.F.; Ernst, W.R. Rate of reaction of chlorine dioxide and hydrogen peroxide. Chem. Eng. J. Biochem. Eng. J. 1995, 60, 101-104. [CrossRef]

23. Burke, M.; Tenney, J.; Indu, B.; Hoq, M.F.; Carr, S.; Ernst, W.R. Kinetics of hydrogen peroxide-chlorate reaction in the formation of chlorine dioxide. Ind. Eng. Chem. Res. 1993, 32, 1449-1456. [CrossRef]

24. Neodo, S.; Rosestolato, D.; Ferro, S.; De Battisti, A. On the electrolysis of dilute chloride solutions: Influence of the electrode material on Faradaic efficiency for active chlorine, chlorate and perchlorate. Electrochim. Acta 2012, 80, 282-291. [CrossRef]

25. Eisenberg, G. Colorimetric Determination of Hydrogen Peroxide. Ind. Eng. Chem. Anal. Ed. 1943, 15, 327-328. [CrossRef] 